\title{
戦災復興都市の高度経済成長期における市街地形成経過と 当初線引き画定との関係に関する研究 \\ A STUDY ON THE RELATION BETWEEN URBANIZED PROCESSES AT HIGH ECONOMIC GROWTH PERIOD AND THE FIRST DESIGNATION BY AREA DIVISION SYSTEM IN CITIES ENFORCING POST-WAR RECONSTRUCTION PROJECT
}

\author{
浅野 純一郎*
}

Junichiro ASANO

\begin{abstract}
This study clarifies the relation between urbanized processes at high economic growth period and the first designation by area division system in cities enforcing Post-War Reconstruction Project (PWRP) from comparative analysis for 17 local cities. Consequently, the followings are concluded mainly: 1 . While all cities has similar condition as large-scale enforcement of PWRP, urbanized processes at high economic growth period are different. 2. Its urbanized process is related with the first designation of area division and the transition ways are divided into seven patterns. 3. Characteristics on extending places of land use zones and land readjustment project at high economic growth period are also different from those after area division.
\end{abstract}

Keywords: Cities enforcing Post-War Reconstruction Project, U rbanized Process, High Economic Growth Period,

Area Division System, Land Readjustment Project, Land U se Zones

戦災復興都市, 市街地形成経過, 高度経済成長期, 線引き制度, 土地区画整理, 用途地域

\section{1. 研究の背景と目的}

空襲による焼け野原から再出発した戦後の都市計画は、戦災都市 においては戦災復興土地区画整理（以下、復興区画整理と略）の実 施が国策として進められ、高度な計画技術を実装しつつ、復興の象 徵として、あるいは近代都市計画像の具現化の場として、各都市で 事業成就されたのは周知のことである。しかし、戦地からの引揚者 や経済復興の進展による都市への人口集中は急速であり、1946 1960 年間の人口増が 1.5 2.5 倍に達する都市が一般的であった。 当然のことながら、これらの人口は復興区画整理事業区域内に収容 できず、その周辺部を含めて新市街地が形成されていったが、高度 経済成長期の人口集中とこれに伴うスプロール（都市拡大）への土 地利用計画的対策は、1968 年都市計画法による区域区分制度から、 つまり急速な人口拡大期の後である。こうした経過をみた場合、戦 災復興から高度経済成長期（あるいは当初線引き直前まで）におけ る市街地形成経過は、当時の計画課題に加え、今日の既成市街地の ルーツを把握する上で重要であると考えられる。つまり、スプロー ル市街地や低密度分散型市街地の形成といった地方都市にほぼ共 通する今日の土地利用計画課題に対し、復興区画整理の実施とその 周辺部の基盤整備推進との関係性、各都市のこの時期の市街地整備 (用途地域の拡大の仕方や基盤整備の実施レベル等) のあり方、こ の市街地整備と当初線引きの画定との関係性といった観点は、今日 の計画課題の起因を含むものと考えられる。また、こうした構造的
な起因は多数対象の比較から全体との関係を通じて把握できるも のと考えられる。よって本研究は、高度経済成長期における戦災復 興都市の市街地形成経過を、用途地域の拡大や土地区画整理事業の 伸展等、土地利用計画的観点から対象都市の多数同時による比較研 究を通して、主に量的かつ場所的に明らかにし、加えてこの特性と 当初線引き画定との関係に言及することで今日的土地利用課題の 起因を考察することを目的とする。

人口増加に伴う市街地の拡大を用途地域指定や基盤整備の程度 との関係から捉え都市計画課題に言及寸る研究は、高度経済成長期 以降、特に線引き制度の導入後に本格化しており、戦災復興期から 高度経済成長期を対象とした研究は非常に少ない。例外として、明 治〜昭和 30 年代の熊本を対象とした、公共施設移転配置等を通し てみた市街地形成研究 1)2 や や明治末～昭和 50 年代前半の仙台を対象

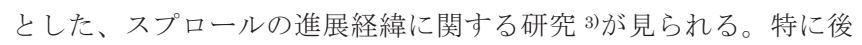
者は居住地の拡大を問題にしている点で本研究の関心に近いが、複 数都市を対象にしていない点、市街地拡大を基盤整備との関係で捉 えていない点、線引き制度等の土地利用計画との関係を見ていない 点等、本研究とは趣旨が異なっている。他方で、区域区分の当初画 定とその後の市街地拡大経過との関係については、市街地拡大の量 的推移の特性と課題（過大な市街化区域指定の問題）之、質的推移 と課題（低密度・低未利用地の存在）の双方が明らかにされている 4)5)。これに対し本研究は区域区分の当初画定の特性や要因をそれ以
* 豊橋技術科学大学建築・都市システム学系 教授・博士 (工学)
Prof., Dept. of Architecture and Civil Engineering, Faculty of Engineering, Toyohashi University of Technology, Dr.Eng. 
前の経緯に求めて考察するものである。また、人口減少に伴う都市 縮小のあり方が課題とされる今日では 2014 年に立地適正化計画が 施行され、市街地範囲の縮小化が検討されている。既成市街地の形 成経過を基盤整備との関係から分析する本研究は、市街地縮小化を 検討する上でも居住誘導区域指定に関わる基盤整備済み地域の考 え方等で基礎的知見を提供すると考える。

\section{2. 研究の方法}

戦災復興期から当初線引き画定後までの比較的長期において、か つ複数都市を対象とする本研究では、市街地形成経過の推移を各期 共通で比較検討できるという理由から、人口構造（DID 含む）、用 途地域、区画整理の 3 つの指標を主に扱う。対象都市としたのは、 復興区画整理面積 $200 \mathrm{ha}$ 以上の地方の線引き都市 26 であり 注 1 、こ の内、資料調查注 2)で回答のあった表 1 に示寸 17 市を対象とした。 本研究の目的に照らし、市街地拡大の規模、範囲·場所、市街化 の質に密接に関係する、前出の 3 指標（人口構造、用途地域、区画 整理）を基に都市分類を行い、分類された都市グループ毎の特色や 都市グループ間の関係及びその時期的変容から市街地形成（つまり、 実質的な土地利用計画の実施経過)の特性を明らかにし、その上で、 この特性と今日の土地利用計画課題との関係を考察する。よって、 研究の具体的フローとして、3 章では(1)高度経済成長期の市街地形 成経過を前述の 3 指標の量的変化から都市分類を行い (3-2 節)、そ の上でその変遷過程の場所的特性を分析する (3-3 節)。同様に、4 章では(2)当初線引き前後における 3 指標の量的変化から都市分類を 行い (4-2 節)、当初線引き画定の場所的特性を分析した上で (4-3 節)、(1) と (2)の都市分類間の関係から高度経済成長期の市街地形成 経過と当初線引き画定との関係を考察する (4-4 節)。両者の関係に ついては、将来人口推計方法の差異における影響を別に検討してい る $(4-1$ 節 $) 。 3$ 章及び 4 章は多数の調査都市の比較によるマクロ分 析であるのに対し、5 章では高度経済成長期の市街地形成と当初線 引き画定に特徵的関係の見られる 4 グループ 7 タイプを抽出し、市 街地形成経過の特性をケーススタディとして明らかにする。ここで は、主に用途地域指定の拡大、実質的市街地の拡大、区画整理の展
開の 3 つの観点から 7 つの移行タイプがもつ本質的な土地利用計画 課題に言及寸る。さらに 6 章では、全体を総括すると共に、高度経 済成長期の市街地形成経過がもつ土地利用計画課題と今日の課題 との関係を考察する。

本研究の調查時期区分であるが、復興区画整理事業の完了時（対 象都市では概ね 1958 年）と当初線引き時の 2 時点を設定した。そ の上で、敗戦から復興事業完了時点を戦災復興期、それ以降から当 初線引き時を線引き直前期、当初線引き時から概ね全市で線引きが 完了した 1975 年を線引き直後期と記し、1950 年代から線引き直前 期を合わせて高度経済成長期として記す。ただし、復興区画整理事 業完了時点や当初線引き時点は各都市で一定しない一方、人口動向、 用途地域、区画整理のデータを同時点で揃えることが難しい為、各 期の分析で引用する各データは適宜各々の時点に合わせて引用し ている注3)

\section{3. 戦災復興都市の高度経済成長期における市街地形成経過の特色 3-1. 調査対象都市の人口動向及び用途地域指定経過}

表 1 及び表 2 では、対象都市の高度経済成長期における人口動向、 市街地の広がり（市町村合併経過や DID）、用途地域指定経過、土 地区画整理事業（以下、区画整理と略）施行経過を一覧している。 1946 年 1970 年間の人口増加率は $400 \%$ 近く（広島や長岡）から $120 \%$ 程度（大牟田）の範囲に全市が位置しており、15 市が $200 \%$ 以上を記録している。この増加は昭和の大合併の影響にもよるが、 対象都市における市町村合併が少なかった 1960１970 年間でみて も人口増加率はほぼ $120 \%$ 超であり、合併の影響を除いてもなお人 口増加が急であったことが判る。さらに DID に注目すると、母都 市以外の旧合併市町に飛び地の DID を持つ事例（飾磨市を合併し た姫路等）は少ないこと、人口総数に占める DID 人口の割合（DID 人口率) は 1960 年と 1970 年であまり変わらないことから (表 1)、 線引き直前期までの人口増加は市町村合併による増加というより DID を中心とした既存の都市構造の中で吸収されたと見られる。た だし 1960 年〜1970 年にかけて DID 人口密度は、広島と呉を除く 全市で一貫して減少しており、1975 年 DID では全都市で減少して

表1 対象都市の人口、市町村合併数、DID、産業施策一覧

\begin{tabular}{|c|c|c|c|c|c|c|c|c|c|c|c|c|c|c|c|c|c|c|c|c|c|c|c|}
\hline \multirow[b]{3}{*}{ 番 } & \multirow[b]{3}{*}{$\begin{array}{l}\text { 対象都 } \\
\text { 市 }\end{array}$} & \multicolumn{5}{|c|}{ 人口※1 } & \multicolumn{4}{|c|}{ 市町村合併数※2 } & \multicolumn{11}{|c|}{ DID $※ 3$} & \multicolumn{2}{|c|}{ 産業施策 } \\
\hline & & \multirow[b]{2}{*}{\begin{tabular}{|c} 
戦災復興 \\
期(1946 \\
年)
\end{tabular}} & \multirow[b]{2}{*}{ 1960年 } & \multirow[b]{2}{*}{ 1970年 } & \multicolumn{2}{|c|}{ 增加率 (\%) } & \multirow[b]{2}{*}{\begin{tabular}{|c|}
1940 \\
$\sim$ \\
1945 \\
年 \\
\end{tabular}} & \multirow[b]{2}{*}{$\begin{array}{c}1946 \\
\sim \\
1960 \\
\text { 年 }\end{array}$} & \multirow[b]{2}{*}{$\begin{array}{c}1960 \\
\sim \\
1970 \\
\text { 年 }\end{array}$} & \multirow[b]{2}{*}{$\begin{array}{c}1971 \\
\sim \\
1975 \\
\text { 年 }\end{array}$} & \multicolumn{4}{|c|}{ 1960年DID } & \multicolumn{5}{|c|}{ 1970年DID } & \multicolumn{2}{|c|}{ 1975年DID } & \multirow{2}{*}{\begin{tabular}{|l} 
新 \\
産 \\
業 \\
都 \\
市
\end{tabular}} & \multirow[b]{2}{*}{$\begin{array}{l}\text { 工業 } \\
\text { 整倫 } \\
\text { 特別 } \\
\text { 地域 }\end{array}$} \\
\hline & & & & & $\begin{array}{c}1946 \sim \\
\text { 1960年 } \\
\text { 間 }\end{array}$ & $\begin{array}{l}1960 \sim \\
1970 \text { 年 } \\
\text { 間 }\end{array}$ & & & & & \begin{tabular}{|l} 
面皘 \\
$\left(\mathrm{km}^{2}{ }^{2}\right)$
\end{tabular} & $\begin{array}{l}\text { 人口密 } \\
\text { (ha) }\end{array}$ & $\begin{array}{l}\operatorname{DiD} 人 \\
\text { 口率 }\end{array}$ & $\begin{array}{l}\text { 戦蓬復擧 } \\
\text { 占占有率 } \\
\text { (\%) }\end{array}$ & \begin{tabular}{|l|} 
面積 \\
$\left(\mathrm{km}^{2}\right)$
\end{tabular} & $\begin{array}{l}\text { 人口密 } \\
\text { /ha) }\end{array}$ & $\begin{array}{l}\text { DID } 1 \\
\text { 口率 }\end{array}$ & $\mid \begin{array}{l}1966 \text { 年用 } \\
\text { 途地域内 } \\
\text { 占有率 } \\
(\%)\end{array}$ & $\begin{array}{l}\text { 当初市街 } \\
\text { 化区域内 } \\
\text { 占有率 } \\
(\%)\end{array}$ & $\begin{array}{l}\text { 面皘 } \\
\left(\mathrm{km}^{2}\right)\end{array}$ & $\begin{array}{l}\text { 人口密 } \\
\text { ( } \\
\text { /ha) }\end{array}$ & & \\
\hline 1 & 仙台 & 225,036 & 425,272 & 545,065 & 189.0 & 128.2 & 5 & 1 & 0 & 0 & 33.0 & 101.8 & 79.0 & 80.2 & 51.4 & 85.5 & 80.6 & 31.7 & 43.2 & 70.6 & 75.4 & 0 & \\
\hline 2 & 長岡 & 43,475 & 148,254 & 162,262 & \begin{tabular}{|l|}
341.0 \\
\end{tabular} & 109.4 & 0 & 9 & 0 & 0 & 8.7 & \begin{tabular}{ll|}
88.6 \\
\end{tabular} & 52.0 & 68.2 & 11.1 & 80.6 & 55.2 & \begin{tabular}{|l|l|}
61.4 \\
\end{tabular} & 39.6 & 15.5 & 69.2 & & \\
\hline 3 & 豊橋 & 115,226 & 215,515 & 258,547 & 187.0 & 120.0 & 0 & 3 & 0 & 0 & 11.0 & 100.4 & 51.2 & 40.0 & 18.1 & 77.5 & 54.3 & 31.1 & 36.3 & 23.0 & 67.7 & & $\mathrm{O}$ \\
\hline 4 & 静岡 & 194,013 & 328,819 & 416,378 & 169.5 & 126.6 & 0 & 4 & 0 & 0 & 18.8 & 122.4 & 70.0 & 81.9 & 32.0 & 91.5 & 70.3 & 102.6 & 54.4 & 46.1 & 75.4 & & \\
\hline 5 & 岐阜 & 147,701 & 304,492 & 385,727 & 206.2 & 126.7 & 6 & 8 & 0 & 0 & 15.9 & 128.0 & 60.8 & 58.2 & 28.2 & 93.6 & \begin{tabular}{|l|l|}
68.4 \\
\end{tabular} & 102.9 & 50.0 & 35.9 & 79.4 & & \\
\hline 6 & 富山 & 131,005 & 207,266 & 269,276 & 158.2 & 129.9 & 12 & 1 & 2 & 0 & 19.1 & 66.9 & 61.7 & 84.0 & 25.6 & 59.3 & 56.4 & 85.3 & 40.9 & 15.4 & 59.0 & 0 & \\
\hline 7 & 姫路 & 174,466 & 328,689 & 408,353 & 188.4 & 124.2 & 0 & $18(1)$ & 0 & 0 & 23.3 & 69.0 & 48.9 & 32.0 & 44.5 & 54.4 & 59.3 & 40.3 & 43.9 & 56.1 & 47.7 & & $\mathrm{O}$ \\
\hline 8 & 和歌山 & 152,901 & 285,155 & 365,267 & 186.5 & 128.1 & 8 & 10 & 0 & 0 & 21.4 & 82.1 & 61.6 & 99.4 & 33.7 & 75.4 & 69.5 & 156.5 & 54.0 & 44.2 & 62.8 & & \\
\hline 9 & 広島 & 136,518 & 431,336 & 541,998 & 316.0 & 125.7 & 0 & 3 & 0 & 8 & 43.6 & 93.3 & 94.4 & 119.6 & 48.7 & 103.4 & 92.9 & 90.4 & 39.9 & 78.8 & 86.1 & & \\
\hline 10 & 吳 & 169,963 & 210,032 & 235.193 & \begin{tabular}{|l|}
123.6 \\
\end{tabular} & 112.0 & 2 & 3 & 0 & 0 & 23.9 & 74.8 & 85.1 & 74.5 & 26.2 & 77.6 & 86.5 & 80.3 & 77.4 & 29.7 & 70.9 & & \\
\hline 11 & 岡山 & 107,690 & 260,733 & 375,106 & 242.1 & 143.9 & 0 & 12 & 0 & $9(1)$ & 13.6 & 113.9 & 59.4 & 45.0 & 27.0 & 81.0 & 58.3 & 44.2 & 29.7 & 34.7 & 71.5 & 0 & \\
\hline 12 & 高松 & 93,484 & 228,172 & 274,367 & 244.1 & 120.2 & 5 & 10 & 0 & 0 & 11.1 & 108.1 & 52.6 & 103.6 & 26.0 & 65.7 & 62.3 & 87.2 & \begin{tabular}{l|l|}
58.4 & \\
\end{tabular} & 29.4 & 61.0 & & \\
\hline 13 & 松山 & 127,367 & 238,604 & 322,902 & 187.3 & 135.3 & 9 & 4 & 0 & 0 & 13.8 & 102.8 & 59.4 & 110.3 & 22.0 & 83.1 & 56.6 & 64.2 & \begin{tabular}{l|l|}
37.7 \\
\end{tabular} & 36.3 & 66.0 & & \\
\hline 14 & 今治 & 46,802 & 100,082 & 111,125 & 213.8 & 111.0 & 1 & 5 & 0 & 0 & 6.2 & 94.3 & 58.4 & 79.5 & 7.8 & 80.3 & 56.4 & 70.4 & 47.5 & 9.8 & 65.4 & 0 & \\
\hline 15 & 大牟田 & 144,177 & 205,766 & 175,143 & 142.7 & 85.1 & 4 & 0 & 0 & 0 & 21.7 & 72.6 & 76.5 & 58.6 & 23.1 & 56.8 & 74.9 & 60.8 & \begin{tabular}{l|l}
59.2 \\
\end{tabular} & 27.8 & 47.8 & O & \\
\hline 16 & 熊本 & 206,016 & 373,922 & 440,020 & 161.5 & 817.7 & 3 & 10 & 1 & 0 & 25.9 & 106.3 & 73.6 & 47.7 & 41.6 & 83.4 & 78.8 & 76.6 & 46.6 & 51.0 & 74.3 & 0 & \\
\hline 17 & 鹿児島 & 123,533 & 296,003 & 403,340 & 239.6 & 136.3 & 0 & 1(1) & 0 & 0 & 19.2 & 120.1 & 77.9 & 115.4 & 32.4 & 94.6 & 76.0 & 93.2 & 46.8 & 42.6 & 82.9 & & \\
\hline
\end{tabular}

※1:戦災復興期は戦災復興誌の記述による。1960年及び1970年は国勢調査による。※2:用途地域指定区域や市街化区域の構成に関係するものに限った数。()内の数字は、

市の場合。※3: 「戦災復興地域内占有率」は、戦災復興用途地域面積に対する1960DID面積の割合を示す。1966年用途地域や当初市街化区域も同じ。 
表2 対象都市の用途地域指定及び土地区画整理の関連諸属性一覧



いる。これに関しては、1960 年 DID 内の人口が短期間で減少する とは考えにくい為、新たな低密度な DID が加わったことで全体の DID 人口密度が低下したものと見られる。

これに対し、用途地域指定の経過では、戦災復興用途地域注 4) 1966 年（線引き直前期）の間で、各都市の拡大格差が非常に大き い(表 2)。その為、用途地域に占める DID の面積割合（表 1 の用 途地域内占有率）のレベルや推移もまた各都市で格差が大きく一定 しない。例えば、線引き直前期に用途地域を拡大した結果、DID の 用途地域内占有率を低下させる都市が多い中で（仙台等）、用途地 域の拡大を抑制した結果、占有率が上昇した都市も見られる（和歌 山等 : 表 1)。つまり、人口増加に対し定期的に用途地域を拡大する というシステムが存在しなかった為、用途地域指定の運用が都市間 で大幅に異なっていたことが判る。

区画整理の施行箇所を基盤整 備実績としてみた場合注 5)、対象都 市では 1960 年当時の DID 内区画 整理面積率は 9.7 62.1\% (平均 $31.2 \%$ ）であり（表 2 の「(1) /1960DID 面積 $(\%) 」) 、$ 復興区画 整理の実施を主要因として総じ て高くなっている。しかし、戦災 復興用途地域内での実績として 範囲を広げ、さらに線引き直前時 へと時期を下ってみると、区域数 や面積が増加する都市（豊橋、岐 阜等）からほとんど変化がない都 市 (今治や松山等) まで、はば広 く存在し、基盤整備経過も多様で あることが判る。以上のように、 人口の増加傾向や DID の拡大経
過は比較的類似するのに対し、用途地域指定や区画整理の実施経過 は様々である。次節ではこれらの指標を総合し、市街地形成経過に よる都市分類を試みる。

\section{3-2. 市街地形成経過による都市分類}

表 1 及び表 2 における用途地域、DID、区画整理実績の各指標よ り、高度経済成長期の各々の変化率を求め、主成分分析を行った。 各変化率指標は表 3 に掲げるが、用途地域拡大率、DID 面積拡大率、 DID 人口密度変化率、用途地域内の区画整理面積拡大率、DID 内 の区画整理面積包含率の変化率、用途地域内の区画整理面積包含率 の変化率を用いた。累積寄与率が $90 \%$ を越えた第三主成分まで求 め（表 4）、各カテゴリの固有ベクトルから（表 3）、第一主成分を 用途地域拡大性、第二主成分を区画整理拡大性と解釈した。第三主 成分は、DID の区画整理包含率の変化率が特に寄与することから、 表3 戦災復興〜当初線引き期における市街地形成経過に関わる主成分分析指標及び固有ベクトル一覧

\begin{tabular}{|c|c|c|c|c|c|c|c|c|c|c|c|c|}
\hline \multirow[b]{3}{*}{ 番号 } & \multirow[b]{3}{*}{$\begin{array}{c}\text { 対象都 } \\
\text { 市 }\end{array}$} & \multicolumn{6}{|c|}{ (戦災復興 ) 線引き直前期 } & \multicolumn{5}{|c|}{ 線引き直前時 線引き直後期 } \\
\hline & & \multirow[b]{2}{*}{$\begin{array}{l}\text { 用途地域 } \\
\text { 用途地域 } \\
\text { 应大率 } \\
\text { (戦災用 } \\
\text { 途 } \rightarrow 1966 \\
\text { 用途) }\end{array}$} & \multicolumn{2}{|c|}{ DID } & \multicolumn{3}{|c|}{ 区画整理実績 } & \multirow[b]{2}{*}{\begin{tabular}{|l} 
用途地域 \\
用途地域拡 \\
大率(線引 \\
き直前＼cjkstart当 \\
初市街化区 \\
域)
\end{tabular}} & \multicolumn{2}{|c|}{ DID } & \multicolumn{2}{|c|}{ 区画整理 } \\
\hline & & & $\begin{array}{l}\text { DID面積 } \\
\text { 拡大率 } \\
(1960 \text { 年 } \\
\rightarrow 1970 \\
\text { 年) } \\
\end{array}$ & $\begin{array}{l}\text { DID人口 } \\
\text { 密度変化 } \\
\text { 率(1960 } \\
\text { 年 } \rightarrow 1970 \\
\text { 年) }\end{array}$ & \begin{tabular}{|l} 
区画整理面 \\
積拨率 \\
災復興用途 \\
呙 1 1966角 \\
途地域内) \\
\end{tabular} & \begin{tabular}{|l} 
区画整理包 \\
念率変化率 \\
(1960DID \\
$\rightarrow$ \\
1970DID)
\end{tabular} & $\begin{array}{l}\text { 区画整理包 } \\
\text { 含率変化率 } \\
\text { 戦災用途地 } \\
\text { 成内途地域内) }\end{array}$ & & \begin{tabular}{|l} 
DID面積 \\
拡大率 \\
$(1970$ 年 \\
$\rightarrow 11975$ \\
年 $)$ \\
\end{tabular} & $\begin{array}{l}\text { DID人口 } \\
\text { 密度変化 } \\
\text { 率(1970 } \\
\text { 年 } \rightarrow 1975 \\
\text { 年) }\end{array}$ & $\begin{array}{l}\text { 区画整理拡 } \\
\text { 大率(線引 } \\
\text { き直前用途 } \\
\text { 地域 } \rightarrow \text { 線引 } \\
\text { き直後) }\end{array}$ & $\begin{array}{l}\text { 区画整理包变 } \\
\text { 率変化 } \\
\text { (1966年用 } \\
\text { 途地域 線 } \\
\text { 引き直後) } \\
\end{array}$ \\
\hline 1 & 仙台 & 3.9439 & 1.5576 & 0.8394 & 1.1998 & 0.6821 & 0.3042 & 0.7327 & 1.3735 & 0.8824 & 3.7653 & 5.1392 \\
\hline 2 & 長岡 & 1.4177 & 1.2759 & 0.9103 & 1.5242 & 0.8980 & 1.0751 & 1.5484 & 1.3964 & 8584 & .8566 & .1990 \\
\hline 3 & 豊橋 & 2.1162 & 1.6455 & 0.7724 & 1.8659 & 0.7198 & 0.8817 & 0.8552 & 1.2707 & 8732 & .0361 & 2115 \\
\hline 4 & 静岡 & 3588 & 1.7021 & 7476 & 1.9363 & 7626 & 4250 & 1.8859 & 1.4406 & 240 & .3526 & .7172 \\
\hline 5 & [岐阜 & 1.0029 & 1.7736 & 0.7312 & 1.4049 & 0.8263 & 1.4008 & 2.0576 & 1.2730 & 8486 & 1.2792 & 16217 \\
\hline 6 & 富山 & 1.3189 & 1.3403 & 0.8868 & 1.0944 & 1.3321 & 0.8298 & 2.0883 & 0.6016 & 935 & 1.2147 & .5817 \\
\hline 7 & 姫路 & 1.5176 & 1.9099 & 0.7885 & 1.1038 & 2.2474 & 0.7273 & 0.9190 & 1.2607 & 3757 & .2353 & 3442 \\
\hline 8 & 和歌山 & 1.0000 & 1.5748 & 0.9177 & 1.0691 & 0.7211 & 1.0691 & 2.8984 & $1.3 \cdot 16$ & 8330 & .1786 & .4067 \\
\hline 9 & 広島 & 1.4783 & 1.1170 & 1.1077 & 1.0000 & 0.9088 & 0.6764 & 2.2651 & 1.6181 & 8326 & 1.1155 & .4925 \\
\hline 10 & 吳 & 1.0168 & 1.0962 & 1.0381 & 1.1753 & 1.0721 & 1.1559 & 1.0366 & 1.1336 & 9129 & 1.0000 & 19647 \\
\hline 11 & 岡山 & 2.0182 & 1.9853 & 0.7114 & 1.3826 & 0.6837 & 0.6850 & 1.4913 & 1.2852 & 8822 & 1.4340 & .9616 \\
\hline 12 & 高松 & 2.7847 & 2.3423 & 0.6082 & 1.1245 & 0.4370 & 0.4038 & 1.4918 & 1.1308 & 281 & 1.2055 & 18081 \\
\hline 13 & 松山 & 2.7401 & 1.5942 & 0.8084 & 1.1029 & 0.6918 & 0.4025 & 1.7039 & 1.6500 & 7937 & 1.1652 & .6838 \\
\hline 14 & 今治 & 1.4214 & 1.2581 & 0.8513 & 1.0000 & 0.7949 & 0.7035 & 1.4814 & 1.2564 & 8145 & 1.0000 & 0.6750 \\
\hline 15 & 大牟田 & 1.0276 & 1.0645 & 0.7826 & 1.0565 & 0.9925 & 1.0281 & 1.0257 & 1.2035 & 0.8411 & 1.0000 & 0.9749 \\
\hline 16 & 熊本 & 1.0000 & 1.6062 & 0.7845 & 2.4297 & 1.2610 & 1.5325 & 1.6444 & 1.2260 & 8912 & 1.1471 & 0.6976 \\
\hline 17 & 鹿児島 & 2.0887 & 1.6875 & 0.7878 & 1.3153 & 0.6599 & 0.6297 & 1.9939 & 1.348 & 0.8764 & 1.3631 & 0.6837 \\
\hline \multirow{3}{*}{$\begin{array}{l}\text { 固有 } \\
\text { ベク } \\
\text { トル }\end{array}$} & 第一 & 0.89183 & 930 & 559 & .12316 & 9854 & 6075 & 27507 & 950 & 402 & 6946 & 3882 \\
\hline & 第二 & 0.10856 & 0.41448 & -0.15700 & 0.75874 & -0.27736 & 0.37303 & 0.90925 & 0.08521 & -0.01259 & 0.40081 & .07212 \\
\hline & 第三 & 0.13175 & 0.35263 & -0.07407 & 0.13582 & 0.91147 & -0.05989 & -0.09065 & 0.97797 & -0.18130 & 0.00101 & -0.04982 \\
\hline
\end{tabular}


表4 主成分分析結果一覧

\begin{tabular}{|c|c|c|c|c|c|c|}
\hline & \multicolumn{3}{|c|}{ 戦災復興〜線引き直前期 } & \multicolumn{3}{|c|}{ 線引き直前～直後期 } \\
\hline & 第一主成分 & 第二主成分 & 第三主成分 & 第一主成分 & 第二主成分 & 第三主成分 \\
\hline 寄与率 & $65.93 \%$ & $15.20 \%$ & $11.33 \%$ & $84.42 \%$ & $12.34 \%$ & $2.57 \%$ \\
\hline 累積寄与率 & $65.93 \%$ & $81.13 \%$ & $92.47 \%$ & $84.42 \%$ & $96.76 \%$ & $99.32 \%$ \\
\hline 成分解釈 & $\begin{array}{l}\text { 用途地域拡 } \\
\text { 大性 }\end{array}$ & $\begin{array}{l}\text { 区画整理拡 } \\
\text { 大性 }\end{array}$ & $\begin{array}{l}\text { 市街地充実 } \\
\text { 性 }\end{array}$ & \begin{tabular}{|l} 
区画整理充 \\
実性
\end{tabular} & $\begin{array}{l}\text { 用途地域拡 } \\
\text { 大性 }\end{array}$ & $\begin{array}{l}\begin{array}{l}\text { 市街地拡大 } \\
\text { 性 }\end{array} \\
\end{array}$ \\
\hline
\end{tabular}

表7 戦災復興〜線引き直前期の市街地形成経過の関係

\begin{tabular}{|c|c|c|c|c|c|c|}
\hline & \multicolumn{5}{|c|}{ 戦災復興～線引き直前期 } \\
\hline & & $\begin{array}{l}\text { 3)用途 } \\
\text { 掋大·区 } \\
\text { 画整理 } \\
\text { 拡大 }\end{array}$ & $\begin{array}{l}\text { (1)用途 } \\
\text { 超拡大. } \\
\text { 区画整 } \\
\text { 理微增 }\end{array}$ & $\begin{array}{l}\text { (2)用途微 } \\
\text { 兾·掂整 } \\
\text { 理拡大 }\end{array}$ & $\begin{array}{l}\text { (5)用途微 } \\
\text { 増·区画停 } \\
\text { 带·市街地 } \\
\text { 充実 }\end{array}$ & $\begin{array}{l}\text { (4)用途微 } \\
\text { 壃·区整整 } \\
\text { 停滞 }\end{array}$ \\
\hline \multirow{4}{*}{$\begin{array}{c}1960 \\
\text { 年DID } \\
\text { 人口 } \\
\text { 密度 }\end{array}$} & 120人/ha以上 & 鹿児島 & & 静岡、岐阜 & & \\
\hline & $\begin{array}{l}100 \sim 120 人 \\
/ \mathrm{ha}\end{array}$ & $\begin{array}{l}\text { 岡山、豊 } \\
\text { 橋 }\end{array}$ & $\begin{array}{l}\text { 仙台、松 } \\
\text { 山、高松 }\end{array}$ & 熊本 & & \\
\hline & $80 \sim 100$ 人 $/ \mathrm{ha}$ & & & 長岡 & & $\begin{array}{l}\text { 和歌山、広 } \\
\text { 島、今治 }\end{array}$ \\
\hline & 80人/ha未淽 & & & & 姬路 & $\begin{array}{l}\text { 富山、呉、 } \\
\text { 大牟田 }\end{array}$ \\
\hline \multirow{5}{*}{$\begin{array}{c}\text { 戦災 } \\
\text { 復興 } \\
\text { 期区 } \\
\text { 画整 } \\
\text { 理 } \\
\text { トック } \\
\text { ※ }\end{array}$} & 規模小A & & 仙台 & 熊本 & 姫路 & 呉 \\
\hline & 規模小B & & 松山 & 静岡 & & $\begin{array}{l}\text { 和歌山、広 } \\
\text { 島、大甾 }\end{array}$ \\
\hline & 規模大C & 岡山 & & 長岡 & & 今治、富山 \\
\hline & 規模大D & 豊橋 & 高松 & & & \\
\hline & 規模大E & 麀児島 & & 莜阜 & & \\
\hline
\end{tabular}

市街地充実性と解釈した。各都市のカテゴリスコアを基にクラスタ 一分析（ウォード法）を行い、5つのクラスター（以下、CL と略）

に分類した（表 5)。各クラスターの主成分スコアや基とした各指標 の值を参照し、CL1 は用途超拡大・区画整理微増都市群（以下、都 市群を略)、CL2 は用途微増・区画整理拡大、CL3 は用途拡大・区画 整理拡大、CL4 は用途微増・区画整理停滞、CL5 は用途微増・区画 整理停滞・市街地充実と解釈した（表 5、6）注 6)

各都市群と 1960 年 DID 人口密度との関係を見ると（表 7）、100 人/ha 以上の人口密度の高い都市では、用途地域の拡大をしており

（CL1、3 の都市群を含む）、逆に 100 人/ha 未満の人口密度の低い 都市では、用途地域の拡大が少ない傾向が見られる。つまり、実質 的市街地の人口密度の高さが用途地域の拡大に影響したと解釈さ れる。次に戦災復興期までの区画整理ストック（表 2 の 1960 年 DID 内区画整理面積率を基にランク分けしたもの）との関係では、スト ック規模を簡略化して傾向を見るために A と B ランクを規模小、C 〜 E を規模大として見ると、区画整理のストックの大きい都市では 線引き直前期においても区画整理拡大を行っており（CL2、3 の都 市群を含む)、ストックの小さい都市では区画整理微増か、停滞し ていることが判る。このように概ね 1960 年時点の人口構造や区画 整理の整備要件が、線引き直前期の用途地域指定や区画整理整備の 動向に関係していることが判る。

\section{3-3. 市街地形成経過の場所的特性}

本節では、3-2 節の分析時期における市街地形成経過の場所的特 性を分析する。市街地形成経過を計る指標は、用途地域の拡大、実 質的市街地 (DID) の拡大、区画整理の拡大の各々の方向性である。 その結果を表 8 に一覧しているが、用途地域と実質的市街地の拡大 に関しては、市町村合併経過、地形、港湾 ・工業地整備、1960 年 DID との関係、区画整理との関係に特に注目し、表 8 の凡例に示す 基準によって記号判別している。前述した各分析項目は、各々行政 面、地理、産業、人口動態、基盤整備に関連し、場所的特性の基本 事項を網羅すると考える。土地区画整理の方向性では、これらに加 え、他都市との連携軸、復興区画整理、用途地域指定、街路計画と の各関係といった他のインフラとの関係性を把握する要件を含め、
表5「戦災復興〜線引き直前期」と「線引き直前〜直後期」のクラスター分析結果

\begin{tabular}{|c|c|c|c|c|c|}
\hline 期間 & $\begin{array}{l}ク ラ \pi \\
\text { タ-No }\end{array}$ & 該当都市 & 第一主成分 & 第二主成分 & 第三主成分 \\
\hline \multirow{5}{*}{$\begin{array}{l}\text { 戦災 } \\
\text { 復興 } \\
\text { ～線 } \\
\text { 尼 } \\
\text { 直前 } \\
\text { 期 }\end{array}$} & & 仙台、高松、松山 & 1.58543 & 0.05164 & 0.00532 \\
\hline & & 長岡、静岡、岐阜、熊本 & -0.70073 & 0.52509 & -0.00430 \\
\hline & & 鹿児島、岡山、豊橋 & 0.46059 & 0.17911 & -0.06665 \\
\hline & & 4広島、今治、富山、和歌山、大牟田、呉 & -0.50389 & -0.39019 & -0.18080 \\
\hline & & 姫路 & -0.31182 & -0.45143 & 1.28599 \\
\hline \multirow{5}{*}{$\begin{array}{l}\text { 線引 } \\
\text { き直 } \\
\text { 前〜 } \\
\text { 直後 } \\
\text { 期 }\end{array}$} & & 仙台 & 4.75133 & 0.46736 & \multirow{5}{*}{$\begin{array}{l}\text { 数值は主成 } \\
\text { 分得点の平 } \\
\text { 均値。 }\end{array}$} \\
\hline & & 長岡、岡山、高松、熊本、松山、今治 & -0.24232 & -0.08196 & \\
\hline & & 姫路、豊橋、大牟田、呉 & 0.15888 & -0.67486 & \\
\hline & & 静岡、鹿児島、岐阜、広島、富山 & -0.58063 & 0.33400 & \\
\hline & & 和歌山 & -1.02979 & 1.05383 & \\
\hline
\end{tabular}

表 6 戦災復興 線引き直前期と直前期 直後期の市街地形成経過の関係

\begin{tabular}{|c|c|c|c|c|c|c|}
\hline \multirow{2}{*}{\multicolumn{2}{|c|}{$\begin{array}{c}\text { ※: ○記号番号は、表5 } \\
\text { のクラスターNoを示 } \\
\text { す。 }\end{array}$}} & \multicolumn{5}{|c|}{ 戦災復興 線引き直前期 } \\
\hline & & $\begin{array}{l}\text { (3)用途拡 } \\
\text { 大.区画 } \\
\text { 整理拡大 }\end{array}$ & $\begin{array}{l}\text { (1)用途超 } \\
\text { 应大·区画 } \\
\text { 整理微増 }\end{array}$ & $\begin{array}{l}\text { 2)用途微 } \\
\text { 増·区整 } \\
\text { 理拡大 }\end{array}$ & $\begin{array}{l}\text { (5)用途微 } \\
\text { 増·区画停 } \\
\text { 滞·市街地 } \\
\text { 充実 }\end{array}$ & $\begin{array}{l}\text { (4)用途微 } \\
\text { 増·整 } \\
\text { 理停滞 }\end{array}$ \\
\hline \multirow{3}{*}{\begin{tabular}{l|l} 
& \\
線 \\
引 \\
き \\
直 \\
前
\end{tabular}} & $\begin{array}{l}\text { (5)用途超拡大·区 } \\
\text { 画整理極低充実 }\end{array}$ & $I=A$ & & III-A & III-B & \\
\hline & $\begin{array}{l}\text { (4)用途拡大·区画 } \\
\text { 整理低充実 }\end{array}$ & |鹿児島 & & & & 広島、富山 \\
\hline & $\begin{array}{l}\text { (2) 用途拡大 - 区画 } \\
\text { 整理中充実 }\end{array}$ & 岡山 & 松山 & 熊本、長岡 & & 今治 \\
\hline \multirow{2}{*}{$\begin{array}{l}\text { 直 } \\
\text { 後 } \\
\text { 期 }\end{array}$} & $\begin{array}{l}\text { (1)用途縮小·区画 } \\
\text { 整理超完実 }\end{array}$ & $|I-B|$ & 仙台 & & & IV \\
\hline & $\begin{array}{l}\text { (3)用途縮小- - 画 } \\
\text { 整理中充実 }\end{array}$ & 豊橋 & II-A & & 姬路 & 吳、大牟 \\
\hline
\end{tabular}

関連のある区画整理区域の数で示している。

【用途地域と実質的市街地の拡大の方向性】まず市町村合併経過で は、合併自治体を包含しない都市は用途地域で 5 、実質的市街地で 4 しかなく、この両者と市町村合併の関係が非常に強い。つまり、 戦後（あるいは、少なくとも 1940 年以降）に合併した市町区域を 含めて用途指定拡大をする事例や DID 化する事例が多い。典型な 事例として鹿児島の旧谷山市、高松の旧香西町や旧仏生山町、豊橋 の旧二川町や旧石巻村（以上、図 1)、熊本の旧川尻町や旧秋津村、 岐阜の旧茜部村や旧鏡島村等（以上図 2）がある。地形も同様であ り、多くの都市が用途地域の拡大や DID の拡大に対し、地形的制 約を受けている注 7)。東西二面を海と山塊に囲繞され用途地域や DID が南北に延びる鹿児島（図 1）や、市街地北東部を山川（金華 山や長良川）に面し、その方面への拡大がない岐阜（図 2）等、事 例は非常に多い。港湾・工業地整備（概ね 200ha 超の大規模工業 地や港湾整備を含む事例）については、用途地域の×事例には臨海 工業地整備がありながら用途拡大がされなかった事例（和歌山：図 2 和歌山 $\mathrm{a}$ 部）や 1960 年以前（多くは戦前）に工業地整備がされ てきた事例（広島、兝、大牟田 : 図 2 大牟田 $a 、 b$ 部）が含まれる。 これに対し、戦後に工業地整備を進めた都市は「用途地域超拡大」 や「用途地域拡大」の都市群に多いことが判る。典型事例として、 仙台港整備（図 1 仙台 $\mathrm{a}$ 部）と合わせ東部に工業地開発(同 b) 進 めた仙台、臨海工業地整備を進めた高松（図 1 高松 $\mathrm{a}$ 部）、同じく 臨海工業地等、西部に工業地整備を進めた豊橋（図 1 豊橋 $\mathrm{a} 、 \mathrm{~b}$ 部） がある。他方、工業地が DID 化した事例はさらに多く（×は 1 事 例のみ)、多くの都市で線引き直前期において工場立地が実際に進 んだことが判る。例えば、図 1 鹿児島 $\mathrm{a}$ 部、同高松 $\mathrm{a}$ 部、図 2 和歌 山 $\mathrm{a}$ 部、大牟田 $\mathrm{c}$ 部等である。

1960 年 DID と用途指定拡大との関係では、「用途地域超拡大」「用 途地域拡大」の都市群で、DID のはみ出しが特に進んでおり（@や ○判定の都市)、これが用途地域拡大の要因の一つとして考えられ る。例えば、図 1 の 4 市はいずれも 1960 年 DID が戦災復興用途地 域範囲を複数箇所ではみ出ているが、線引き直前期の用途地域はは 


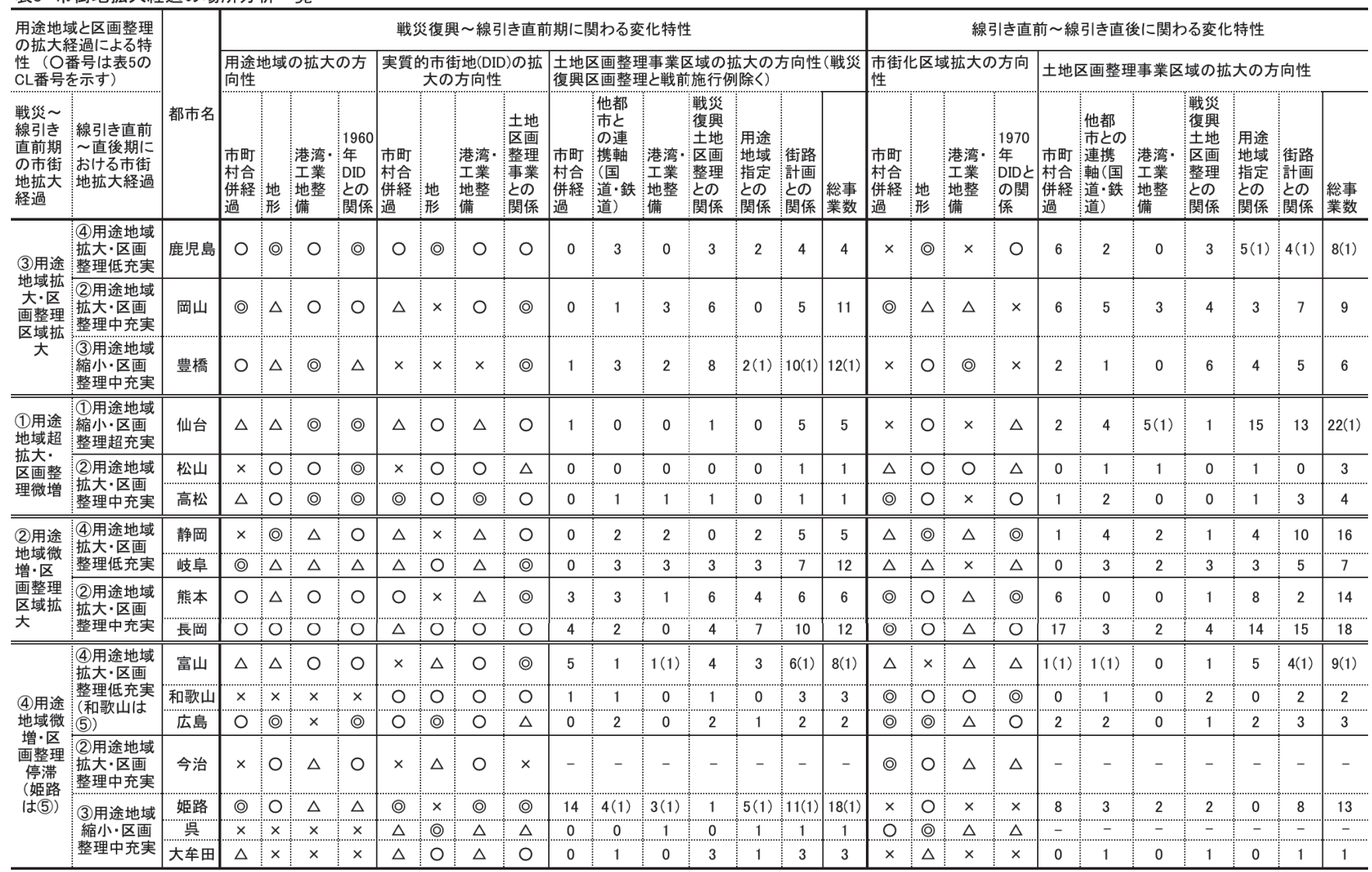

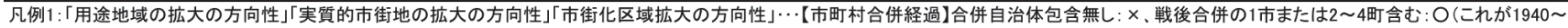
1945年間の場合: $\Delta$ )、戦後合併の5市町以上を含む: @。【地形】拡大の方向への影響が区域の75\%以上で及ぶ場合@、40 75\%が○、10 40\%が $\triangle 、 10 \%$ 未満がx。

【港湾·工業地整備】概ね200ha超の大規模工業地や港湾を含む: @、工業地域指定のまとまった土地を含む: O、準工業地域指定の小区域を含む: $\triangle$ 、無し: $\times$ (戦前でも1940年以降の工業地域整備地は



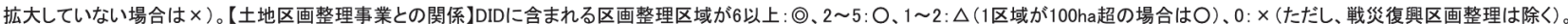
凡例2:「土地区画整理事業区域の拡大の方向性」…該当する区域数を掲載。()内の数字は100ha以上の大規模事例の数。「」は区画整理実績が無いにとを示す。【市町村合併経過】戦後に編入した 市町村内での実績。【他都市との連携軸】都市間を連絡する国道や鉄軌道を含む事例数。【港湾·工業地整備】工業地域や準工業地域での事例数。【戦災復興土地区画整理との関係】戦災復興区画整理に 直接もしくは間接に接続する事例数。【用途地域指定区域との関係】用途地域指定境界部での事例数。【街路計画との関係】幅員 $12 \mathrm{~m}$ 超の都市計画街路を1本以上含む事例数。尚、ここでの区画整理総 事業数は、「戦災復興〜線引き直線期」が1965年までに着工があったもの、「線引き直前〜直後期」が1966-1971年間に着工のあったもので集計している。よって表2の集計とは数値の異なる部分がある。

み出た方面を中心に拡大していることが判る。逆に、DID がはみ出 ていながら用途地域の拡大を控えている都市もあり（図 2 の和歌山 等)、用途指定の指定方針は都市によって差が大きい。実質的市街 地の拡大の方向性と区画整理実施と関係では、「区画整理拡大」「区 画整理停滞」の都市群の区別を問わず、ほぼ全ての都市で区画整理 実施地区は 1970 年に DID 化していることが判る。例えば、図 1 鹿児島 $b 、 c$ 部、仙台 $c$ 部、豊橋 $c$ 部、図 2 熊本 $a$ 部、岐阜 $a \sim d$ 部 が該当する。

【区画整理の拡大の方向性】表 8 では、区画整理の実施状況は事業 数で示しているが、各都市群に共通して該当することに、総事業数 のほとんど（低い事例でも岡山の 45.6\%）は幹線街路を含めて実施 されていることがある（表の「街路計画との関係」では幅員 $12 \mathrm{~m}$ 以上の都市計画街路を 1 本以上含む区画整理をカウントしている)。 次に、線引き直前期用途地域の境界付近で実施された事例を「用途 地域指定との関係」でカウントしているが、熊本や長岡では割合が 高いものの、他の都市では総じて低く、むしろ「復興区画整理との 関係」(復興区画整理区域に直接または間接に接続する事例) 注8)に 該当する事例が多い。つまり、この時期は郊外の飛び地的な区画整 理ではなく、都心部の市街地に接続する形での区画整理が中心だっ たと見られる。典型事例として、豊橋（図 1）や岐阜、大牟田、熊
本（図 2) がある。また「市町村合併経過」では、姫路、富山、熊 本、長岡といった合併した市町で区画整理事例が多い事例も見られ るが、むしろこれらは例外であり、線引き直前期ではこうした事例 は少なかった。これは当時の区画整理が都心に近い部位で行われる 傾向にあったことを補足すると考える。

4. 高度経済成長期における市街地形成経過と当初線引き画定と の関係

\section{4-1. 人ロフレーム方式導入の影響}

本章では、当初線引き画定の特性と高度経済成長期の市街地形成 経過との関係を分析するが、その前に市街地の区域規模を決定する 方法がどのように当初線引き画定に関係したのかを確認する。線引 き制度導入後は、定期線引き見直しが概ね 5 年毎になされ、市街化 区域拡大が人口動向に合わせて行われる人口フレーム方式が導入 されている。他方で、計画収容人口を市街地の利用面積と計画人口 密度を掛けて算出した上で、直線回帰式に基づく将来人口推計值で 割ることで、計画年限を割り出す方法は戦前の初期都市計画から行 われており 6)、戦災都市土地利用計画設定標準によれば、その基本 的枠組みは戦災復興都市計画でも同じである注 9)。そこで、同設定 標準による平均的計画人口密度（1ha あたり 150 人）を用途地域面 
積にかけ、基準となる時点の人口で割った計画収容人口倍率を比較 した（表 2)。これによると、戦災復興用途地域においても、1966 年用途地域においても各都市の倍率は非常に格差が大きいのに対 し(計画年限でみた場合、 -1 年から 168 年まで)、線引き後の 1980 年市街化区域では $104 \sim 174 \%$ で比較的安定していることが判る。 即ち、線引き制度では 10 年後の計画人口を設定するよう人口フレ 一ム方式で制度化されたのに対し、旧都市計画法では計画年限の指 定がなかった為、用途地域の指定規模が都市によってバラバラであ ったことを反映する。よって、1966 年用途地域で計画年限が異常 に大きい仙台、姫路、豊橋では、当初の市街化区域面積は 1966 年 用途地域面積より削減されており（表 2）、逆に計画年限が 20 年に 満たないような都市では、市街化区域は大幅に拡大されている（和 歌山や岐阜)。このように、人口フレーム方式の導入が当初線引き 指定の画定規模に影響した。

\section{4-2. 当初線引き画定による都市分類}

当初線引き画定の特性を分析寸る為に、用途地域、DID、区画整 理実績の各指標より線引き直後期の各都市の変化率を求め、主成分 分析を行った。各変化率指標は表 3 に掲げるが、用途地域拡大率、 DID 面積拡大率、DID 人口密度変化率、用途地域内の区画整理面 積拡大率、用途地域内の区画整理面積包含率の変化率を用いた注 ${ }^{10)}$ 。 累積寄与率が $100 \%$ に近くなる第三主成分まで求め（表 4)、各カテ ゴリの固有ベクトルから（表 3）、第一主成分を区画整理充実性、第 二主成分を用途地域拡大性、第三主成分を市街地拡大性と解釈した。
次に、寄与率の低い第三主成分を外して各都市のカテゴリスコアを 基にクラスター分析（ウォード法）を行い、5つの CL に分類した （表 5)。各 CL の主成分スコアや基とした各指標の值を参照し、 CL1 は用途縮小・区画整理超充実都市群（以下、都市群を略）、CL2 は用途拡大・区画整理中充実、CL3 は用途縮小・区画整理中充実、 CL4 は用途拡大·区画整理低充実、CL5 は用途超拡大・区画整理極 低充実と解勫した（表 6)。つまり、用途地域拡大経過で見ると、拡 大しているのは CL5、4、2（拡大の度合いは CL4 > CL2）、縮小は CL1、3 であり、区画整理の充実度では、充実度が高いのは CL1の み、これに続くのが中充実の CL3、2 の順であり、CL4、5 は低く なっている。

\section{4-3. 当初線引き画定の過程における場所的特性}

【市街化区域拡大の方向性】当初線引き画定における各都市の場所 的特性を前節の都市分類毎に見ると（表 8)、市町村合併経過では、 用途地域拡大をした都市群（CL5、4、2）を中心に○記号が多く、 この傾向は戦災復興〜線引き直前期よりも強いことが判る。これは 当初市街化区域の指定が、線引き直前期の用途指定区域境界部のさ らに外側で行われるようになった結果、戦後合併された旧町村域を より多く含むようになったことを反映する。事例として、図 1 高松 の旧仏生山町や旧一宮町、旧円座村、図 2 熊本の旧御幸町や旧託麻 村、旧龍田村、同和歌山の旧西脇町や旧有功村、旧西和佐村等があ る。また、旧用途地域指定範囲よりも当初市街化区域の範囲が広が った結果、その境界が山地や水域に接する事例が増え、地形的制約



図1戦災復興期から当初線引き時における用途地域範囲と区画整理範囲の拡大経過 その1
を受けやすくなった他（図 1 鹿児島の d、e 部や図 2 和歌山の $\mathrm{b}$ 部)、市街化区 域は非可住地を穴抜け状 の市街化調整区域として 指定する事例も多い（図 2 熊本の $\mathrm{b}$ 部等)。従って、 線引き直前期に比べ地形 的制約を受ける事例が増 えている（表 8)。逆に、港 湾・工業地整備では、準工 業地域指定の小区域を市 街化区域に編入する程度 の事例が大半であり（ $\triangle$ 記 号の事例）、線引き直前期 に見られた大規模工業地 や港湾部の新規指定事例 は一部を除き、ほとんど見 られなくなっている（豊橋 の事例は図 1 豊橋の d 部の 追加)。同様に、1970 年 DID との関係においても、 紀の川以北の DID を用途 地域指定していなかった 和歌山（図 2) や 1970 年 DID が線引き直前期用途 地域の境界に迫っていた 
熊本（図 2 熊本の $\mathrm{c} 、 \mathrm{~d}$ 部等）の事例はあるものの、総じて DID の 拡大が市街化区域の拡大に影響した都市は少なくなっている。以上 のように、当初市街化区域指定の場所的特性は線引き直前期とは特 性が異なっていることが判る。

【区画整理事業拡大の方向性】まず、「市町村合併経過」に関係す る事例（合併市町村における施行事例）の数が、約半数の都市で線 引き直前期よりも増加している点や（鹿児島、岡山、長岡等 : 表 8)、 「用途地域指定との関係」（市街化区域境界部での施行事例）の数 も増加している点（鹿児島、豊橋、仙台等多数）を指摘できるが、 これらは線引き直後期の区画整理は既成市街地やその周辺ではな く、市街化区域縁辺で主に行われるようになったことを反映する。 事例としては、図 1 鹿児島、仙台、豊橋や図 2 熊本、岐阜（各都市 の $1966 \sim 1975$ 年間の実施事例）がある。一方で、「復興区画整理 との関係」においても、松山等 4 市を除く全市に事例があり、復興 区画整理に連続する形での基盤整備の拡大が依然行われている。具 体的事例として、図 1 鹿児島 $\mathrm{f} 、 \mathrm{~g}$ 部、同豊橋 $\mathrm{e}$ 部、図 2 和歌山 $\mathrm{c}$ 部、同大牟田 $\mathrm{d}$ 部、同岐阜 $\mathrm{e} 、 \mathrm{f}$ 部等があり、大規模な復興区画整 理を実施した都市における基盤整備拡大経過の特色だと考えられ る。

「街路計画との関係」では、線引き直前期に引き続き幹線街路を 含む区画整理事例が多くなっており、都市間や地域間を結ぶ国道や
鉄道といった連携軸上での実施事例 (「他都市との連携軸」の事例) も多くの都市で複数の事例が見られる。こうした事例は線引き直前 期でも見られたが（図 1 高松 $\mathrm{b}$ 部や同豊橋 $\mathrm{f}$ 部、図 2 和歌山 $\mathrm{d}$ 部、 同大牟田 $\mathrm{e}$ 部等)、線引き直後期ではさらに郊外部において行われ る事例が多い。例えば、図 1 鹿児島 $\mathrm{h}$ 部（線引き直前期）に対する $\mathrm{g}$ や $\mathrm{i}$ 部、図 2 岐阜 $\mathrm{d}$ 部に対する $\mathrm{e}$ 部は典型で、各々の都市の南北 軸、東西軸上で区画整理が連続的に郊外へと展開している。こうし た事例は他にも非常に多い。逆に、「港湾・工業地整備」において 大規模工業地を整備寸る事例は仙台のみであり（図 1 仙台 $a 、 b$ 部）、 その他は準工業地域を含む事例である。線引き直後期において区画 整理で大規模な工業地整備を行う事例は非常に少なくなった

4-4. 高度経済成長期の市街地形成経過と当初線引き画定との関 係性

戦災復興から線引き直前期における市街地形成特性による都市 分類（3-2 節）と 4-2 節での都市分類をクロス分析することによっ て、高度経済成長期の市街地形成経過と当初線引き画定との関係性 を見ると（表 6)、I .線引き直前期に用途拡大をし、線引き直後期 にも用途拡大をした都市群（鹿児島等 4 都市）と、II.逆に用途縮 小した都市群（豊橋、仙台）、III.線引き直前期に用途拡大が微増程 度で、線引き直後期に用途拡大に転じた都市群（静岡等 8 市）、IV 逆に縮小か、ほとんど拡大しなかった都市群（呉、大牟田）の 4 つ

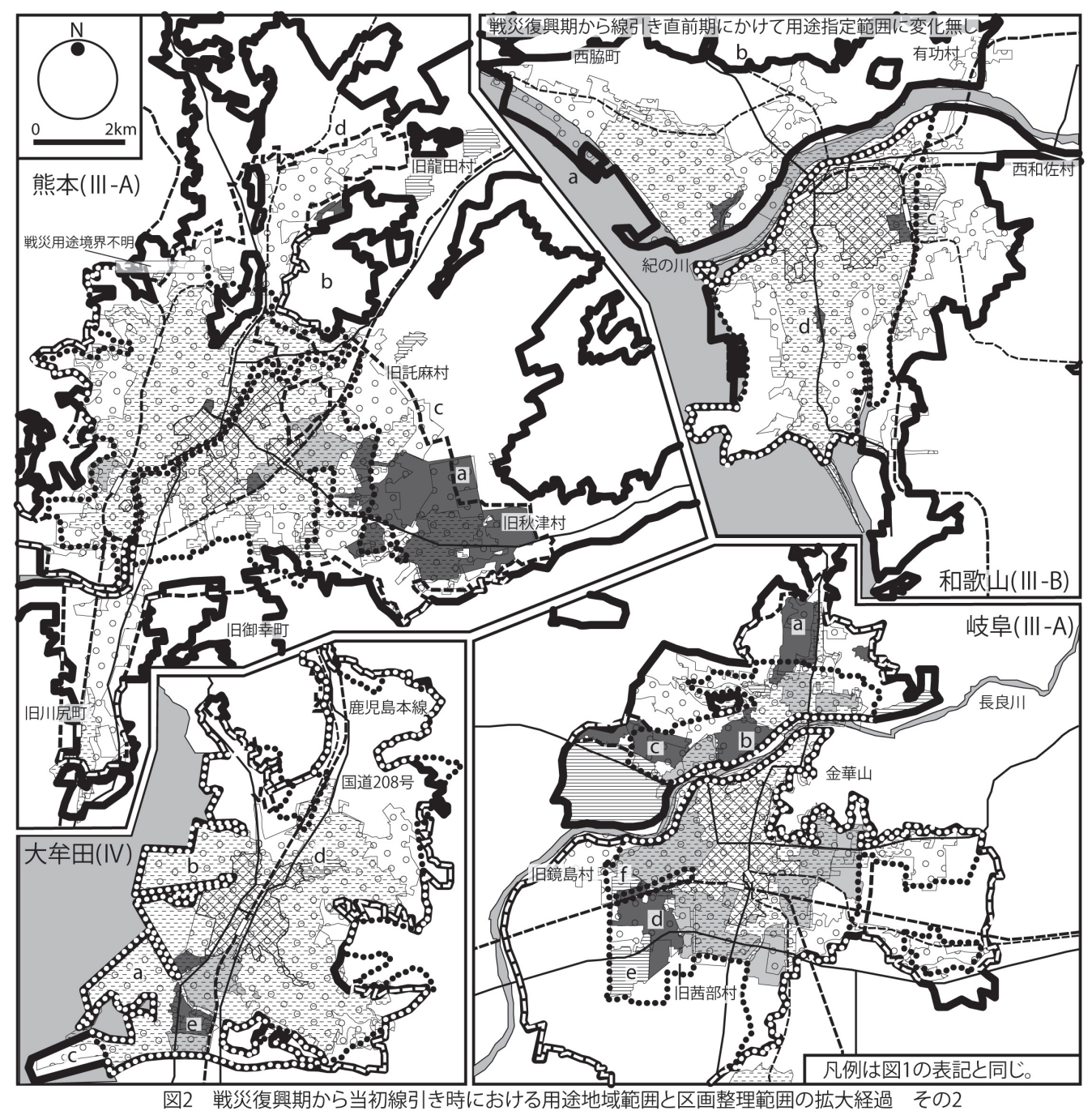

に分けることができる注11。

さらに I では、線引き直前 期に区画整理拡大を行い、線 引き直後期にも区画整理事例 を増加させている鹿児島、岡 山（以上 I -A、区画整理実施 数等は表 2) と直前期の区画整 理実績が少ない上、直後期に も増加程度が低い松山、高松 （I -B）といった対照的な 2 グループに分けられる。II で は線引き直前期に区画整理の 実績が少なかったが、線引き 直後期に急拡大させた仙台 （II -A） と、直前期に区画整 理拡大が進み、直後期にも市 街化区域内区画整理包含率を 上昇させている豊橋（II -B） に分けられる。IIIでは、線引 き直前期に区画整理拡大を行 い、線引き直後期にも区画整 理事例を増加させている静岡 等 4 市（III-A） と線引き直前 期に区画整理実績が少ない上、 直後期にも市街化区域内包含 率を大きく低下させている和 歌山等 4 市（III-B）に分けら れる。IVの 2 市では、線引き 直前期に区画整理実績が少な 
い上、直後期にも事例がほとんどなく、しかし用途縮小をした為、 市街化区域内区画整理包含率が維持されている点で共通する。

この 7 つの移行タイプの内、線引き直前期か直後期に用途拡大を しながら、区画整理の蓄積が少ない I - B と III-B の都市群は、人口 増加に伴うスプロール市街地化を引き起こした懸念がある都市群

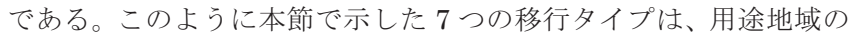
拡大と区画整理の実施経過を主な尺度としながらも、各々がその経 過から固有の土地利用計画課題を有寸ることが推察される。よって、 次章では移行タイプ毎にこの内容を見る。

\section{5. 個別都市に見る戦災復興期から当初線引き画定に至る市街地 形成経過}

\section{5-1. 線引き直前期と線引き直後期の双方で用途拡大した都市}

本章では、前節で分類した 7 つ移行タイプ毎に ${ }^{\text {注 }}{ }^{12)}$ 、用途地域 指定の拡大、実質的市街地の拡大、区画整理の展開の 3 つの観点か ら市街地形成経過の特性をケーススタディし、土地利用計画課題を 整理する。鹿児島は高度経済成長期に用途拡大及び区画整理拡大を し、線引き直後期にも区画整理事例を増加させている事例（ I -A） である。復興区画整理面積は $1034.7 \mathrm{ha}$ と最大級で、これが戦災復 興用途地域に占める包含率も $62.2 \%$ と非常に大きい点に特色があ る(表 2 )。こうした恵まれた基盤整備の蓄積を活か寸形で、戦災復 興〜線引き直前期には旧谷山市を含む南方へ用途地域を拡大して おり（図 1)、合わせてこの方面での区画整理を進めていった。これ らは着実に 1970 年DIDの受け典として機能している。このように、 山地に囲繞されて市街化区域の拡大が少ない西部を含め、全体とし て見ると、西部や南部において線引き直後期に区画整理が追加され、 実質的市街地の展開に先駆けた基盤整備を準備している事例と言 える。他方で、市街地北方への用途地域の拡大が遅れ、DID のはみ 出しを後追い寸る形で当初市街化区域を拡大指定しているが、この 方面では区画整理実施が遅れており、ここに課題がある。

高松は復興区画整理面積（358.7ha）や戦災復興用途地域内の包 含率 $(43.0 \%$ : 表 2) が高いものの、線引き直前期及び直後期の双 方で区画整理実績が少ない事例（I-B）である。戦災復興用途地域 の範囲は 1960 年 DID に対してコンパクトであったことや（図 1 、 表 1 の戦災復興用途地域内占有率 $103.6 \%$ )、市街地南部に広い平地 を有することから DID の面積的拡大が大きく（表 1)、これに対応 する為に線引き直前及び直後期に大幅に用途拡大をしている (表 2 )。 しかし、区画整理の実施はわずかであり、基盤未整備地区への DID の広がりが著しく、当初市街化区域指定地での実施事例も非常に少 ない。復興区画整理の蓄積がありながら実質的市街地の展開に対し て基盤整備が後追いに転じた事例と言える。つまり、郊外の基盤整 備に大きな課題を抱えている事例である。

\section{5-2. 線引き直前期に用途拡大し線引き直後期に用途縮小した都市}

本節では、線引き直前期に用途拡大をしながら線引き直後期に用 途縮小した仙台と豊橋を取り上げる。2 市が直後期に用途縮小した 理由は 4-1 節で述べているが、区画整理実施経過は全く異なってい る。仙台では線引き直前期に区画整理の実施が少なく、線引き直後 期には逆に区画整理事例を急増させている（II -A）。戦災復興用途 地域が実質的市街地に対し狭く（表 1：1960 年 DID の戦災復興用 途地域内占有率が $80.2 \%$ )、塩䆞方面（東部） への工業地開発計画
があった仙台では注 13)、線引き直前期に用途地域面積を 3.9 倍に拡 張させた（表 2)。線引き直前期の区画整理は比較的都心に近い場所 や用途地域境界部で行われているものの規模が小さい為、DID の受 け皿となる部分は少なく（図 1)、広大な基盤未整備 DID が発生し ている。逆に線引き直後期の区画整理は DID 外で主に展開されて おり、将来の市街化に備えた形となっている。従って、当初市街化 区域指定地の郊外部よりも既成市街地の基盤未整備地区に問題を 抱えた事例と言える。

豊橋では（II-B）、戦災復興用途地域が当時の実質的市街地に対 して比較的広かったが（表 1 : 戦災復興用途地域内占有率 40\%)、 工業整備特別地域の指定を受け線引き直前期にさらに用途拡大を 行った（市街地東南部の臨海部（図 1 豊橋 $\mathrm{a} 、 \mathrm{~b}$ 部）や東部の東海 道沿線等）9。これに対し区画整理の実績は戦前のものを含め、復 興区画整理区域から連続する形で市街地の東部や南西部へ継続的 に進められた（図 1）。よってこれらの方面は基盤整備地が DID の 受け典となり、さらに将来の市街化に先駆けて基盤準備する形とな っている。しかし、南方への都市間連携軸である国道 259 号沿線で は基盤未整備 DID が発生している他、当初市街化区域指定が相対 的に過大である為（表 $1: 1970$ 年 DID の当初市街化区域内占有率 が $36.3 \%$ と低い)、依然区画整理の実施規模に課題がある事例と言 える。

\section{5-3. 線引き直前期に用途微増で線引き直後期に用途拡大に転じ た都市}

線引き直前期から直後期にかけて継続的に区画整理の実績を積 み上げた岐阜（III-A）は、戦前期の蓄積を含めて最も基盤整備の行 き届いた事例である（表 2 : 区画整理の当初市街化区域内包含率は $36.9 \%$ で最大)。戦後の区画整理地は復興区画整理区域や戦前施行 区域に接続し、ほぼ一体の基盤整備済み市街地をくみ上げており (図 2)、1970 年 DID の 51.3\%（当時の区画整理実績值で計算） をカバーしている。しかし線引き直前期以降に用途地域拡大の進ん だ南西部や東部では、線引き直後期に区画整理の実施事例が非常に 少ない。従って拡大した市街化区域における区画整理の実施継続に 課題のある事例と言える注 ${ }^{14)}$ 。

線引き直前期に戦災復興用途地域からの拡大がなく、当初線引き 時に大幅に市街化区域を拡大した和歌山は、他方で戦災復興以降の 区画整理実績の非常に少ない事例である（III-B）。和歌山市は紀の 川以北の旧 6 町村を 1940〜1942 年に合併編入していたが（図 2)、 当時の用途地域範囲は旧和歌山市内に据え置かれ、この方面が用途 地域に指定されたのは当初線引き時においてである。よって 1960 年 DID や 1970 年 DID は戦災復興用途地域から北部や東部で広く はみ出ていたが、区画整理の実施も対象期間を通じて低調であった。 よって既成市街地と当初市街化区域指定部の双方に渡り、広大な基 盤未整備区域を抱えることとなった事例である。

\section{5-4. 線引き直前期に用途微増で線引き直後期に用途拡大してい ない都市}

石炭工業都市として戦前に隆盛した大牟田市は、1960１970 年 時には寸でに人口減少に転じた成熟都市である (IV、表 1$)$ 。よって、 用途地域は戦災復興都市計画から線引き直前期、同直後期にかけて ほとんど変化がない（表 2、図 2)。これに対し区画整理は戦前期実 施のものを含め、復興区画整理に接続する形で、着実に一体の基盤 
整備市街地をくみ上げてきた。また線引き直後期における区画整理 (図 2 大牟田 $\mathrm{d}$ 部) も DID 外のような郊外部ではなく、DID 化し ている既成市街地で実施されている。人口減少に転じ市街地拡大が 見込めない中で区画整理の実施事例も低調化しているものと考え られるが、既成市街地には基盤未整備地区を抱えており、こうした 地区での区画整理実施が課題であると言える注 15)。このように、各 移行タイプは、高度経済成長期から当初線引きにかけての市街地形 成経過に由来する固有の土地利用課題を持つことが判る。

\section{6. まとめ}

\section{6-1. 各章の総括}

以下に本研究の知見として、戦災復興都市の高度経済成長期にお ける市街地形成経過と当初線引き画定との関係をまとめ、今日の土 地利用計画課題との関係を考察する。

(1)本研究の対象都市は大規模な復興区画整理を実施した点で同じ 戦後の出発点を持つ。しかし高度経済成長期の市街地拡大経過は、 人口のほぼ一貫した急激な増加と DID の拡大経過（低密度化を伴 う面積拡大）において各都市で共通寸るものの、用途地域指定の手 法（拡大の有無、程度とその時期）や区画整理の実施経過（実施規 模と時期や持続性）において格差が大きい。

(2)高度経済成長期の市街地形成経過を用途地域、DID、区画整理実 績の観点から見ると、用途指定及び区画整理の拡大の程度から 5 つ の都市群に分類が可能である（用途超拡大・区画整理微増、用途微 増・ 区画整理拡大、用途拡大・区画整理拡大、用途微増・ 区画整理停 滞、用途微増・ 区画整理停滞・市街地充実の各都市群)。市街地形成 経過の場所的特性では、市町村合併経過や地形的制約といった要因 から用途拡大や DID 桩大が行われるケースが多く、特に線引き直 前期の用途拡大は 1960 年 DID との関係（DID のはみ出し）が強 く見られる。戦災復興期以降の区画整理実施地が 1970 年 DID に含 まれるケースは非常に多く、実質的市街地化に与えた区画整理の効 果は大きいものと考えられる。また同時期の区画整理は幹線街路を 含む形で、復興区画整理区域に直接乃至間接に接続して実施される 事例が多く、都心近くで行われる傾向がある。

(3)線引き制度導入後の人口フレーム方式が 10 年後の計画人口を念 頭に定期線引き見直しを行うシステムを備えたのに対し、旧都市計 画法下では計画年限の固定や定期的な用途見直しを法制度として 持ち合わせていなかった。その為、各都市の用途地域は計画人口密 度に基づき指定されながら、その規模はバラバラであった。人口フ レーム方式が導入された結果、線引き直前期に用途地域拡大をしな かった都市（和歌山等）は当初線引き時に大幅な拡大を行い、直前 期に過大な用途指定を行っていた都市（仙台や豊橋等）は規模縮小 をして市街化区域指定を行った。

(4)当初線引き画定時の特性を用途地域、DID、区画整理実績の観点 から見ると、区画整理の充実性と用途地域拡大の程度から 5 つの都 市群に分類が可能である（用途縮小・区画整理超充実、用途拡大・区 画整理中充実、用途縮小・区画整理中充実、用途拡大・区画整理低充 実、用途超拡大・区画整理極低充実の各都市群）。当初線引き画定時 の場所的特性では、市街化区域指定が線引き直前期の用途地域指定 部のさらに外側で行われたことで、戦後の合併市町村を含むケース や地形的制約を受けるケースが増えた。また、大規模工業地や港湾
部を含めた用途拡大（市街化区域指定）が少なくなり、DID の拡大 が用途拡大にあまり関係しなくなった点で線引き直前期と特性が 異なる。同時期の区画整理の場所的特性においても、市町村合併経 過に関係する事例や市街化区域指定境界部での施行事例の増加等、 既成市街地やその周辺ではなく、当初市街化区域の縁辺で行われる 事例が増えており、線引き直前期までの特性とは変化が認められる。 (5)高度経済成長期の市街地形成経過と当初線引き画定との関係で は、その移行パターンを 4 グループ 7 タイプに分類できる。第一に、 線引き直前期と線引き直後期で用途拡大しながら、直前期に区画整 理拡大を行い、直後期にもその数を増加させたタイプと（I-A）、 逆に両期で区画整理実績の少ないタイプがある（ I -B）。第二に、 線引き直前期に用途拡大し、線引き直後期に用途縮小したグループ には、直前期に区画整理実績が少ないが直後期に急激に増大させた タイプと（II-A）、直前期に区画整理拡大を行い、直後期にも継続 的施行のあるタイプがある（II -B）。第三に、線引き直前期に用途 微増で線引き直後期に用途拡大に転じたグループには、直前期に区 画整理拡大を行い、直後期にも継続的施行のあるタイプと（III-A） と両期を通じて実機の少ないタイプがある（III-B）。第四に、線引 き直前期に用途微増で線引き直後期に用途拡大していないグルー プは、両期において区画整理の実績が少ない（IV）。

(6)市街地形成経過と当初線引き画定への移行パターンを通し、各都 市の土地利用計画課題を見ると、区画整理実績が総じて少ない I - B やIVでは、基盤未整備地区を既成市街地周辺や郊外の双方に広く抱 えている。逆に戦災復興以降、区画整理実績を比較的連続して蓄積 してきた I-A、II-B、III-A においても、市街化区域内の一部には 基盤未整備 DID や基盤未整備市街化区域指定地を抱えている。よ って、基盤未整備地を当初市街化区域内に少なからず抱えている点 で課題は共通する。

\section{6-2. 今日の土地利用計画課題との関係}

今日の地方都市にほぼ共通して見られる低密度分散型市街地の 形成には当初線引きにおける過大な市街化区域指定が関係すると の指摘があるが 4)、当初線引き時の用途拡大の大きい I - A、I - B、 III-A、III-B の都市群はこの指摘があてはまると考えられる。また、 II 型でも線引き直前期の用途指定範囲が過大であった都市も同様 である。これらの都市の当初線引きにおける用途指定が大きい理由 には当時の市町村合併が関係しており、これが今日の低密度分散型 市街地形成の遠因と考えられる。この中でも、線引き直後期に区画 整理実施の少ない I -B、III-B の都市群は、郊外のスプロール化の 起因をこの時期に有すると言える。

次に、比較的大規模な復興区画整理基盤を持ちながら、線引き直 前期に区画整理実績の少ない、I - B、II - A 、III-B、IVの都市群は 既成市街地にスプロール市街地を抱える懸念のある都市群である。 線引き直前期の区画整理は復興区画整理区域に接続して実施され る事例や、幹線街路を含めて実施される事例が多いことから、これ らの都市では、復興区画整理区域を中心とした既存区画整理基盤の その外側における幹線道路の後背地に基盤未整備区域が広がる点 で類似している。今日の立地適正化計画における居住誘導区域の指 定では、基盤整備の有無は考慮事項の一つと考えられることから、 これらの都市（特に線引き直前期に用途地域の拡大の大きかった I -B、III-B の都市）では同区域の指定の困難や同区域の市街地の質 
の問題が懸念される。

今後の課題として、本研究が対象とした当初線引き画定部のその 後の基盤整備経過の把握やその後の市街化区域拡大との関係とい ったマクロ的研究の継続、さらに区画整理未整備地における市街地 化の実態を区画整理以外の手法による開発の有無や実際の人口の 張り付き方から把握するミクロ的分析への進展がある。

\section{謝辞}

本研究は平成 28 年度 JSPS 挑戦的萌芽研究(課題番号:16K14354、 代表者:浅野純一郎)及び基盤研究(B) (課題番号:16H04472、代表者: 浅野純一郎)の研究助成に基づくものである。ここに謝意を表す。

\section{注}

注1）市街地形成経過は大都市圈都市と地方都市では、市街地の連担性や人 口密度、線引き指定のあり方等で条件が大きく異なる為、本研究は地 方都市を取り上げている。具体的には、三大都市圈（首都圈整備法に よる既成市街地と近郊整備地域、近畿圈整備法による既成都市区域と 近郊整備区域、中部圈開発整備法による都市整備区域）を除く都市で ある。

注2）資料調查は 2015 年 $5 \sim 7$ 月にかけて行い、線引き直前期と当初線引き 後（8種類の用途指定がされた時点）の都市計画総括図、当該市の土地 区画整理実施資料、当初線引き時の「整備・開発又は保全の方針」等 を収集した。尚、対象都市の選定に関し、津は戦災復興誌都市編の記 載の問題から、八幡は市町村合併による市域の拡大規模から同条件で 比較ができない為はずし、加えて資料調查に回答の無かった青森、福 井、福山、徳島、高知、福岡、長崎をはずしている。

注3) 高度経済成長期の市街地形成経過分析 (3 章) では、戦災復興都市計画 の用途地域が 1950 年代の值なのに対し（注 4)）、人口（特にDID）は 1960 年が初発である為、量的分析の $3-2$ 節は厳密には線引き直前期の 変化だけを含めた分析となっている。これに対し場所的分析（3-3 節） では、戦後から戦災復興都市計画による用途地域指定までの期間の区 画整理実績が各都市で少ない為、区画整理では復興区画整理と戦前実 施事例を除いた上で、1945 年から復興事業完了時点のものを一括して 分析している。次に、線引き直前期に関し、人口（DID）については、 1970 年を当初線引き時点としてデータを用いる。用途地域に関しては、 線引き直前期（旧都市計画法による用途地域指定）のデータが各都市 で共通で得られる 1966 年（都市計画年報 1966）でデー夕を引用し、 線引き直後のデータは、線引き後に最初に 8 種類の用途指定がなされ た時点の各都市データ（注 2）の調査による）で引用している。土地区 画整理については、表 2 の作成については、各都市から入手した線引 き直前期の都市計画図の年次に依っている。例えば、表 2 土地区画整 理欄の「線引き直前時用途地域内包含事例」の各数值は、その時点で 完了もしくは着工されていた土地区画整理をカウントしている。これ に対し、図 1 及び図 2 の凡例では、各都市で時点を揃えて表記する為 に、1965 年前後を線引き直前と直後の境として示している（しかし、 この表記差による差異はほとんどない)。

注4）戦災復興用途地域とは、戦災復興誌都市編において記載される用途地 域指定区域である。都市毎に決定時期に差があるが (1952 年 (静岡等) ～1959 年 (今治等) までで 1955 年頃が最も多い)、各都市共通の確度 で扱えることを理由に、本研究ではこれを採用する。

注5）都市によっては、耕地整理や開拓組合による開発地等を含む事例があ るが、各都市で共通して入手・比較できる指標とし、区画整理を用い る。データは注 2)の資料調查によるものとし、原則、公共団体施行に 加え、組合や個人施行を含む。

注6）CL5 に分類される姫路は、1946 年に 7 市町と合併する等、市域を拡大 させており、合わせて基盤整備が戦災復興期から編入市町村で行われ てきた。特に旧広畑町では大規模な区画整理を実施した (952.5haの広 地区区画整理)。これは 1960 年までに竣工したが、その後 1970 年にか けてDID 化が進んだ。こうした経過から、表 3 の DID 内の区画整理包 含率の変化率が非常に高い值を示している。姫路は母都市以外の合併 旧市町で基盤整備を伴い市街化が進んだ点、基盤整備は戦災復興期
（1960 年まで）に大規模に行われた点で特異な事例となっており、線 引き直前期のデータを採用しているここでの主成分分析では、用途微 増・区画整理停滞ながら市街地充実の都市群に分類される。

注7）ただし、表 8 の判定では、用途地域やDID が水際や山際に達している 場合でも、用途地域や DID の拡大のない場合は×判定をしている(「用 途地域の拡大の方向性」における和歌山、吳、大牟田等)。

注8）「復興区画整理に直接、接続する」とは、復興区画整理区域に隣接し て施行される区画整理事例を指す。「間接に接続する」とは、復興区画 整理に接続して施行された区画整理の区域に隣接して施行される事例 を指す。この場合、間に介在する区画整理の区域数に制限を設けない。 つまり、連続的な基盤整備済み区域の広がりを示す為に、間接に接続 する事例をここでは含めている。

注9）戦災都市土地利用計画設定標準の「第 2 市街地配分計画」の 5 では都 市計画区域内に包容しえる人口を概算することを求めており、市街地 区域における利用面積（大きい河川、池沼、緑地、飛行場等の面積を 控除したもの）について全体として 1 ha あたり平均 150 人程度を目処 とするとしている。

注10)線引き直後期の区画整理は用途地域指定の境界部（市街化区域縁辺部） で実績が多く、DID 内のような既成市街地では実績が低い為、高度経 済成長期の分析（3-2 節）で用いていた「DID 内の区画整理面積包含率 の変化率」を外している。

注11)姫路は注 6) で示すように市街地拡大経過が特殊である為、ここでの分 析では除いて考える。

注12)移行タイプに複数事例がある場合のケーススタディ対象地の選定は、 本研究の前提 (1 章) に従い、原則として戦災復興期の区画整理ストッ クの高い都市を選んでいる（表 2 戦災復興期区画整理ストック）。よっ て、I -A では鹿児島、II -A では高松、III-A では岐阜、IVでは大牟田。 ただし、III-B では線引き直前期の用途微増から直後期への用途拡大一 の移行が最も顕著であるという理由で、和歌山を選定している。

注13)仙台の塩鼌方面への工業地開発と外港整備計画は戦前期に遡るが、戦 後においても1950年代初頭にはこれが宿命的課題として仙台開発計画 が立案され (参考文献 7))、新産業都市の指定区域として引き継がれて いった (参考文献 8))

注14) 実際、当初市街化区域指定された南西部や東部においては当初線引き

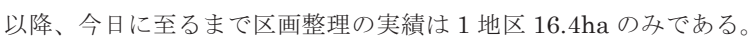

注15)その後今日に至るまで同市の区画整理実績は 3 地区計 46.6 ha に留まっ ており、それ以前の実績（表 2 当初市街化区域内の区画整理面積合計 $527.2 \mathrm{ha})$ の $8.8 \%$ にすぎない。

\section{参考文献}

1）木島安史：熊本市の市街地形成 ---そのの 1 明治以降の歴史的変遷--第 10 回日本都市計画学会学術研究発表会論文集, pp. 193 197, 1975

2）木島安史: 熊本市の市街地形成 - - その 3 市街地における非計画の留 保について---，第 12 回日本都市計画学会学術研究発表会論文集, pp. $139 \sim 143,1977$

3）田中滋夫: 仙台都市圈における市街地形成の過程について $---10 \mathrm{~km}$ 寿 内での市街地拡大を主として---, 第 15 回日本都市計画学会学術研究発 表会, PP.109 114,1980

4）田中洋・中出文平・樋口秀：地方都市における区域区分の当初指定とそ の後の運用に関する研究，都市計画論文集 No.40-3, pp.409〜 414, 2005.10

5）佐藤大樹・松川寿也·佐藤雄哉・中出文平・樋口秀：当初線引き時の市街 化区域と拡大した市街化区域の空間特性の差に関する研究, 都市計画 論文集 Vol.50 No.3, pp.992 997, 2015.10

6) 浅野純一郎：旧都市計画法による最初期の都市計画区域指定に見る計 画技術・思想とその実際に関寸る研究 〜大正期迄に旧都市計画法が 適用された中小都市 43 市を対象として〜，日本建築学会計画系論文集 595 号, pp.125 132, 2005.9

7）内田襄：仙台計画の概要，新都市 7 巻 3 号, p.47, 1952.3

8) 経済企画庁: 新産業都市の指定区域の内定について, 新都市 17 巻 11 号, pp.32 35, 1963.11

9）河合陸郎：東三河工業整備特別地域，新都市 18 巻 12 号, pp.60 64, 1964.12 


\title{
A STUDY ON THE RELATION BETWEEN URBANIZED PROCESSES AT HIGH \\ ECONOMIC GROWTH PERIOD AND THE FIRST DESIGNATION BY AREA DIVISION SYSTEM IN CITIES ENFORCING POST-WAR RECONSTRUCTION PROJECT
}

\author{
Junichiro ASANO* \\ * Prof., Dept. of Architecture and Civil Engineering, Faculty of Engineering, Toyohashi University of Technology, Dr.Eng.
}

Post-War Reconstruction Urban Planning Project is unprecedented all over the world at the viewpoint of the scale and its planning technology and has given much impact to post-war urbanizing process in each city. But the detail and characteristics of its process at especially high economic growth period have been hardly clarified so far. Accordingly, the scope of this study is to clarify those characteristics from comparative investigation of 17 cities enforcing large-scale Post-War Reconstruction Project (PWRP) and to consider the relation between urbanized processes at high economic growth period and the first designation by area division system.

This study is composed of six chapters and includes the analysis of urbanized processes at high economic growth period using multi variable analysis ( $3^{\text {rd }}$ chapter), the analysis of urban planning characteristics after area division and the consideration of relation with the former urbanized processes $\left(4^{\text {th }}\right.$ chapter), and case studies for typical cities $\left(5^{\text {th }}\right.$ chapter). Consequently, this study clarified the followings:

1. While all target cities has similar condition as large-scale enforcement of PWRP, urbanized processes at high economic growth period are various and are divided into five groups. As for locational characteristics of land use zones extension, municipality consolidation and geographical condition are main factors for its area designation.

2. The first designation processes by area division system also are various and are divided into five groups. As for locational characteristics of land use zoning extension, influences of municipality consolidation and geographical condition became stronger because the first designation of urbanized promotion area was enforced in the outside of the former period. Additionally, from inclusion of industrial areas, relation with densely inhabited districts (DIDs), and locations of land readjustment, urbanized process characteristics changed from those at high economic growth period.

3. While new city planning law was established in 1968, old law has no system extending land use zones in line with population increase periodically. This system 'population frame' was established in new law. Therefore area scale of land use zones at high economic growth period was various in each city, but after area division, area scale differences of newly designated urbanized promotion area decreased. Population frame system had much impact to area scale of the first designation.

4. Regarding on the relation between urbanized processes at high economic growth period and the first designation by area division, the transition ways are divided into four groups and seven patterns from the extending scale of land use zones and land readjustment. In addition, from those transition patterns, we can consider planning problems of each city. Especially in cities where land readjustment projects were less progressed from 1945 to 1975 consistently, sprawl areas widely might have been formed from outers of PWRP to the first designation area of urbanized promotion area. But in spite of the cities where land readjustment projects had been enforced continually with PWRP, all land use zones at 1975 and all DID (1970) weren't covered by land readjustment. As for urbanized processes, the extension of land use zones with infrastructure improvement in parallel is common problem in Japanese cities.

(2016 年 2 月 17 日原稿受理, 2016 年 7 月 11 日採用決定) 